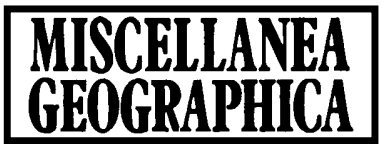

Vol. $13 / 2008$

pp. 105-111

\author{
Bohdan Mucha \\ I. Franko National University of Lviv - Department of Physical Geography \\ e-mail: pbmucha@yahoo.de
}

\author{
Bożena Kicińska, Jolanta Wawer \\ University of Warsaw - Faculty of Geography and Regional Studies - Department of Climatology \\ 00-927 Warsaw, Krakowskieg Przedmieście 30 \\ e-mail: bkicinska@uw.edu.pl,e-mail: jgwawer@uw.edu.pl
}

\title{
DIFFERENTIATION OF THERMAL CONDITIONS IN THE VERTICAL PROFILE OF NATURAL NATIONAL PARK OF CARPATHIANS
}

\begin{abstract}
In the paper, the results of field studies using automatic meteorological stations are presented. The studies were conducted in July 2005 - July 2006 in the vertical profile of Natural National Park of Carpathians. The results show that the thermal conditions in the area under research is strongly differentiated. Particularly large differences have been observed between the lowerings of the terrain (where the range of annual air temperature changes reaches almost $70^{\circ} \mathrm{C}$, exceptionally high and exceptionally low temperature occurs often, and thermal inversions are frequently encountered) and the summit region (where the range of annual air temperature changes barely exceeds $50^{\circ} \mathrm{C}$ and the mean changes of daily air temperature are consideraly smaller).
\end{abstract}

Key words: air temperature, local climate, Natural National Park of Carpathians

The climate of Eastern Carpathians differs from that of the adjacent areas by a relatively low air temperature and high humidity, as well as by larger sums of atmospheric precipitation. Similarly to other mountain areas, the internal differentiation of climatic conditions is strong here; it results from the variety of relief and from the differentiation of exposition and slope inclination. The mean yearly temperature on most of this area is between $3^{\circ} \mathrm{C}$ and $7^{\circ} \mathrm{C}$, the mean 
monthly temperature in January is lower than $-4^{\circ} \mathrm{C}$, and in July it is between $12^{\circ} \mathrm{C}$ and $17^{\circ} \mathrm{C}$. The sums of atmospheric precipitation change between $700-800 \mathrm{~mm}$ in the foreland area and $2000 \mathrm{~mm}$ in the summit region (Zastavnyj, Kusinski 2003).

The dependency of climatic conditions in Eastern Carpathians on absolute altitude has been investigated, among others, by Tokmakova (1957) and Adrianova (1951-1957), who presented the differentiation of thermal conditions in the vertical profile of these mountains. The paper by Tretyak (Tretyak et al. 1982), in which a schematic map of climate mezoregions in the Hoverla Forest District is presented, is also valuable.

Recent research conducted with help of automatic measurement stations allowed to significantly extend and specify the conclusions regarding the spatial differentiation of climatic conditions in the area in question formulated in the papers mentioned above. Earlier, such research was conducted in the areas of Podole, Carpathian Foreland, and in the Beskidy Mountains (Mucha 2004) as well as in the Roztocze area (Mucha 2006).

In this paper, results of topoclimatic research (mainly of air temperature measurements) are presented, for the period July 2005 - July 2006. This research was performed using electronic recording equipment (model Tinytag Ultra TGU-1500) in the catchment area of the upper Prut River, within the National Natural Park of Carpathians. The recording equipment was located in six landscape units along the upper Prut valley, from Pozhizhevska Mountain (1775 m asl) to the town of Yaremche (530 m asl) (Fig. 1). They were installed at 2.0-2.5 above ground level and programmed to read the parameters measured every 60 minutes.

The profile under investigation included two state meteorological stations and the Geographical Station of Lviv University. This made it possible to compare and interpret meteorological data obtained from the automatic stations (which are active only periodically) with the long-time data series from the permanent points of meteorological observations. The comparison of the air temperature values (yearly mean, maximum, minimum and monthly mean in January and in July - see Table 1) from the year-long series of automatic measurements and from the 55-year-long series from meteorological stations shows a large similarity of the analogous values. Thus, we can regard the results from automatic stations as properly reflecting the specific characteristics of the differentiation of thermal conditions in the analyzed area. 
Studies conducted during the period July 2005 - July 2006 revealed great differentiation of thermal conditions in the field profile under investigation.

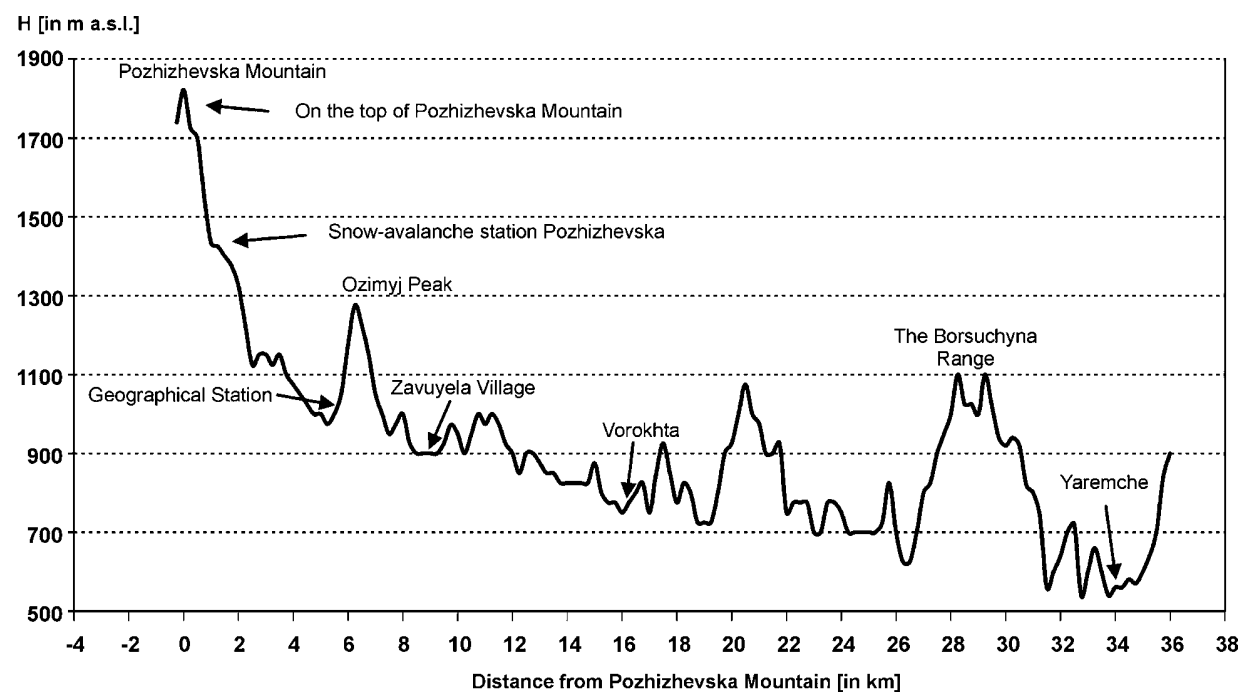

Fig.1. Hipsometric profile of the terrain under study

The annual mean air temperature varied from $6.9^{\circ} \mathrm{C}$ in Yaremche to $0.9^{\circ} \mathrm{C}$ on the Pozhizhevska peak; this shows that absolute altitude has a singnificant influence on the thermal conditions in this region. The influence of relief on air temperature at the points in question was also revealed as regards extremely high and extremely low values of this climate element. The range of temperature changes was $59^{\circ} \mathrm{C}$ in Jaremcze, $53^{\circ} \mathrm{C}$ on Pozhizhevska Mountain and as much as $68^{\circ} \mathrm{C}$ in the village of Vorokhta (on the flattened area of a gently inclined slope, at the altitude $775 \mathrm{~m}$ asl). On the top of Pozhizhevska Mountain air temperature above $25^{\circ} \mathrm{C}$ was recorded only four times in the period July 2005 - July 2006. In the Vorokhta kettle a temperature that high occurred as many as 320 times, including 60 occurrences of temperature value above $30^{\circ} \mathrm{C}$. This constituted $1.3 \%$ and $0.3 \%$ of the total number of measurements, respectively. On Pozhizhevska Mountain no temperature below $-25^{\circ} \mathrm{C}$ was recorded, while in the Vorokhta kettle, where winter inversions of air temperature occur particularly often, there were 30 such cases. Such high occurrence 
of the winter inversions of air temperature also caused a decrease in the differences of thermal conditions in the vertical profile in question during the winter (Fig. 2).

Table 1.

Parameters of air temperature at the measurement stations in Natural National Park of Carpathians in the period July 2005 - July 2006 and in the period 1881-1960

\begin{tabular}{|c|c|c|c|c|c|c|c|c|c|c|}
\hline \multirow{2}{*}{ Station } & \multicolumn{2}{|c|}{ Yearly mean } & \multicolumn{2}{c|}{ Maximum } & \multicolumn{2}{c|}{ Minimum } & \multicolumn{2}{c|}{$\begin{array}{c}\text { Mean } \\
\text { in January }\end{array}$} & \multicolumn{2}{c|}{$\begin{array}{c}\text { Mean } \\
\text { in July }\end{array}$} \\
\cline { 2 - 12 } & 1 & 2 & 1 & 2 & 1 & 2 & 1 & 2 & 1 & 2 \\
\hline Yaremche & 6,9 & 6,7 & 31,8 & 37,0 & $-27,5$ & $-32,0$ & $-6,8$ & $-4,3$ & 18,3 & 17,0 \\
\hline Pozhizhevska & 2,6 & 3,0 & 26,9 & 27,0 & $-23,6$ & $-28,0$ & $-6,7$ & $-7,6$ & 13,5 & 12,4 \\
\hline
\end{tabular}

period 2005-2006 - first column 1

period 1881-1960 - second column 2 (source of data: Pryroda ... 1968, 1973)

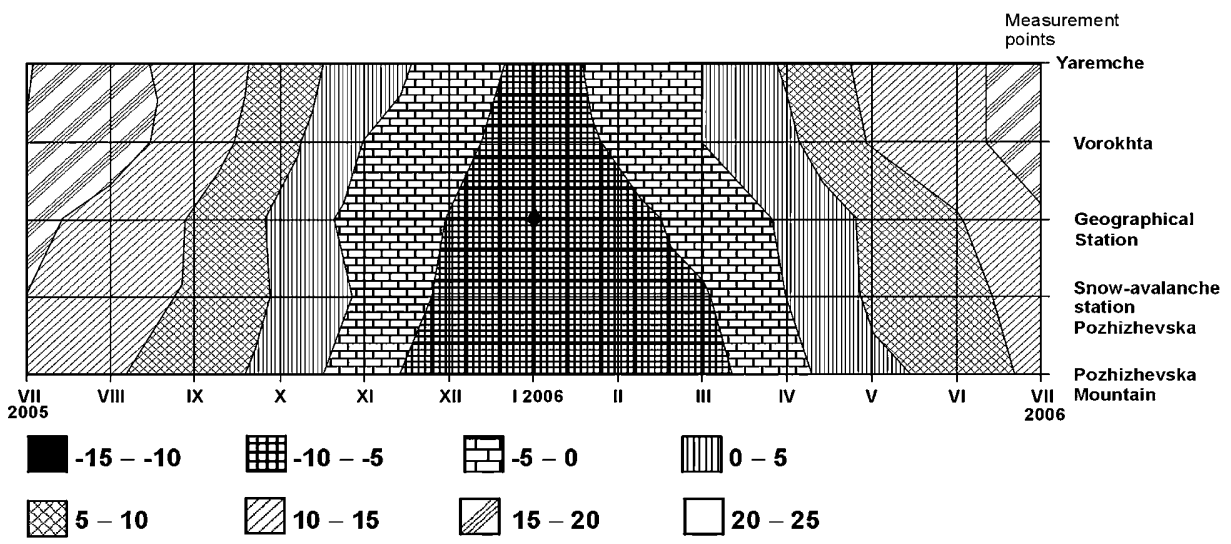

Fig. 2 Differentiation of the monthly mean air temperature in the vertical profile of Natural National Park of Carpathians (July 2005 - July 2006)

The differentiation of thermal conditions in various segments of the analyzed profile is reflected by the comparison of the duration of thermal seasons at various points. For example, thermal summer (the period with the mean daily air temperature above $15^{\circ} \mathrm{C}$ ) is one-fifth as short in the summit region (21 days at Pozhizhevska Avalanche Station) as in lowerings of the terrain of Vorokhta and Yaremche (106 days).

The recognition of the dynamics of the changes of thermal conditions was an exceptionally valuable result of this study. 
Clearly visible differences in the daily development of the air temperature in the lowerings of the terrain, on the slopes and in the summit region were documented; they were marked on days with anticyclonal weather. An excellent example of the influence of relief on the range of air temperature changes was supplied by the observations performed on 23-29 January 2006 (Fig. 3). On these days, the daily amplitude of air temperature in Vorokhta reached $25^{\circ} \mathrm{C}$, while in Yaremche and at the Geographical Station it was $12-15^{\circ} \mathrm{C}$, and on the Pozhizhevska mountain meadow, only $5-10^{\circ} \mathrm{C}$. The large differentiation of thermal conditions in the profile under discussion was caused also by the development of the thermal inversion on days with windless weather in the summer (Fig. 4).

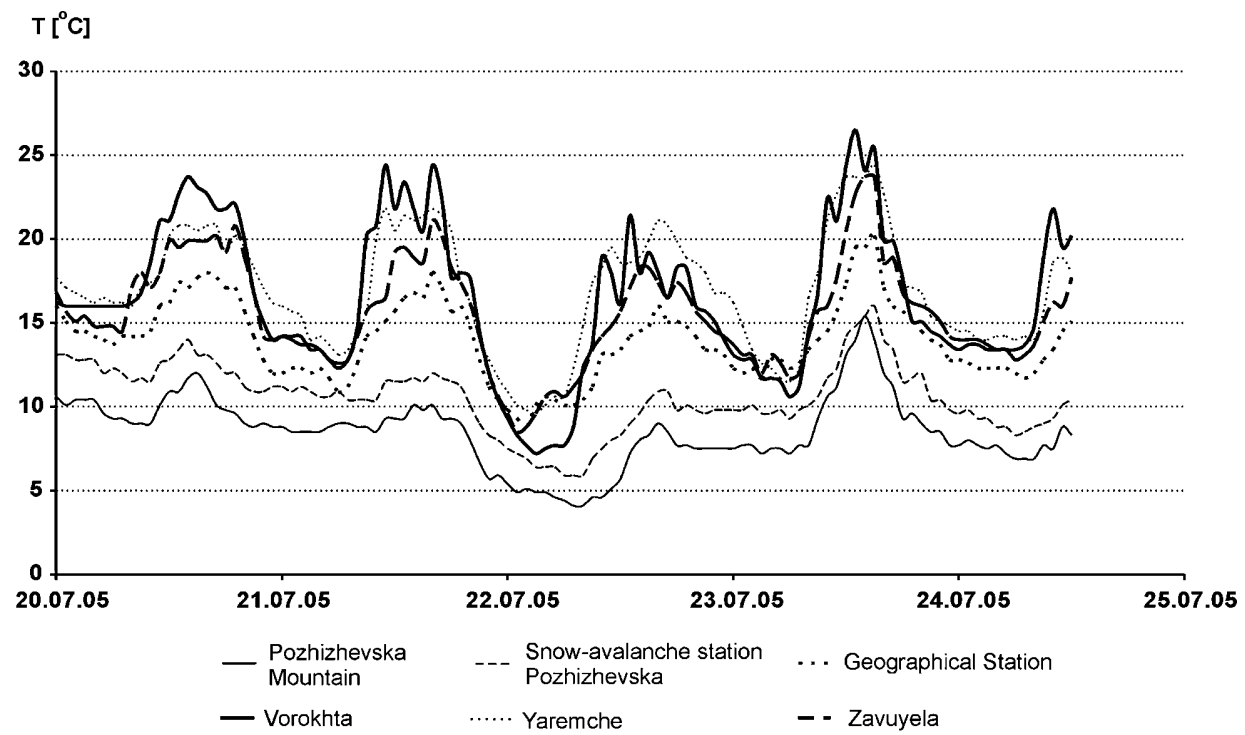

Fig. 3 Air temperature changes at observation points of the vertical profile in Natural National Park of Carpathians in the period 23-29 January 2006

The observation of the changes of thermal conditions on days with anticyclonal weather in the profile under analysis allowed also to confirm the important role of mountain and valley winds in the formation of thermal regime of the area under discussion. It was ascertained that in such conditions the time it takes for cold air masses to flow down from the highest regions to the Geographical Station $(6-10 \mathrm{~km})$ 
is $3-5$ hours; to the Vorokhta kettle (18-20 km), 1 day; and to Yaremche $(32-34 \mathrm{~km}), 2-3$ days.

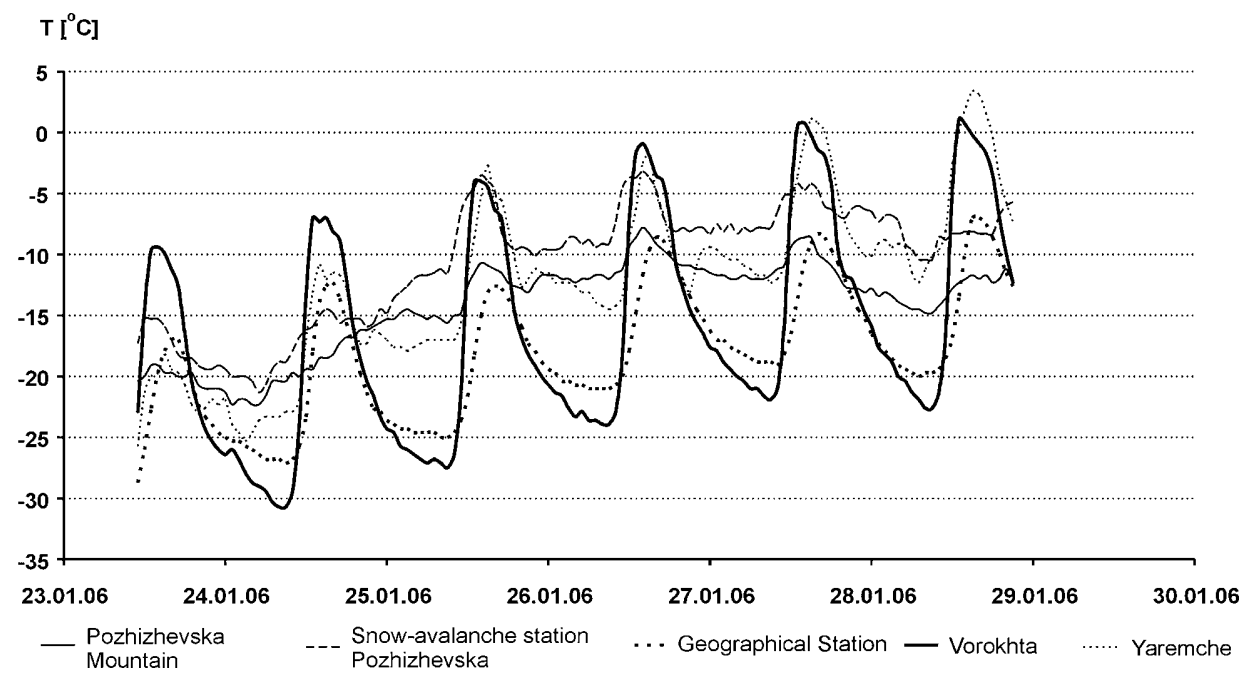

Fig. 4 Air temperature changes at observation points of the vertical profile in Natural National Park of Carpathians in the period 20-25 July 2005

Some of the observations performed allowed also to state that the air temperature in the lower regions of the Eastern Carpathians is markedly influenced by the forests: the largest local modifications of thermal conditions occurred in the period when the mean temperature was $10^{\circ} \mathrm{C}$ to $20^{\circ} \mathrm{C}$, thus during the period of full vegetation.

An integrated comparison of the conclusions presented above allows to distinguish three main terrain units in the profile under analysis. These units, differing as regards their thermal conditions, are:

- Terrain lowerings (with high frequency of occurrence of temperature inversions, exceptionally low mean minimum temperature, often with large range of daily temperature changes): this unit could be divided into valley bottoms and lower parts of valley slopes;

- Slopes elevated above the average range of temperature inversions and thus warmer in such conditions than terrain lowerings (except for these parts which function as channels of cold air flow from higher-elevated areas);

- Summit regions, where air temperature changes corresponding to the altitude are not as large as in the lower-elevated areas. 
Apart from the general conclusions presented above and concerning the differentiation of thermal conditions in the vertical profile of the Natural National Park of Carpathians, the results of the field studies presented here can constitute a basis for more detailed analysis of the space-time changes of air temperature and of other climate elements, in particular for a detailed characteristics of the individual topoclimatic units. These are the goals of the next stages of the analysis of the results of the study described here.

\section{REFERENCES}

Adryanov M. S., 1957, Vertikalnaya termicheskaya zonalnost Sovetskykh Karpat [Vertical Thermal Zonality of Soviet Carpathians; in Russian], Nauch. Zapiski Lvovskovo Hos. Universiteta, vol. 40, Geograf. Sbornik, vypusk 4.

Mucha, B., 2004, Wyniki topoklimatyczne w dorzeczu górnego Dniestru w 2002 roku [Topoclimatic Results in the Upper Dnestr Catchment Area in 2002; in Polish], Acta Agrophysica, PAN, Nr 105, Instytut Agrofizyki im. B. Dobrzańskiego PAN w Lublinie.

Mucha B., 2006, Badania na stacji terenowej Wydzialu Geografii Uniwersytetu Lwowskiego na Roztoczu Poludniowym [Research at the Field Station of the Department of Geography of Lviv University in Southern Roztocze; in Polish], Regionalne Studia Ekologiczno-Krajobrazowe, Problemy Ekologii Krajobrazu, vol. XVI, Warszawa

Herenczuk, K. I. (ed.), 1968, Pryroda Ukrainskikh Karpat [Natural World of Ukrainian Carpathians; in Ukrainian], Lviv, Publ. of Lviv University

Herenczuk, K. I. (ed.), 1973, Pryroda Ivano-Frankovskoy Oblasti [Natural World of the Ivano-Frankovsk Oblast; in Ukrainian], Wyzsza Szkola, Publ. of Lviv University

Tokmakov, O., 1957, Vertykalni temperaturni gradyenty v Ukrainskikh Karpatakh [Vertical temperature gradients in Ukrainian Carpathians; in Ukrainian], Pratse ekspedytsii po kompleksnomu vyvchenyu Karpat i Podkarpatsya, geogr. series vol. 4, Chernivtsi.

Tretyak, P., Stoyko, S., Manko, P., 1982, Klimat, flora i roslynnost Karpatskoho zapovidnyka [Climate, Flora, and Vegetation of Carpathian Park; in Ukrainian], Kyiv, Naukova Dumka

Zastavnyi, F., Kusinski, W., 2003, Ukraina. Przyroda - Ludnosc-Gospodarka [The Ukraine. Nature - Population - Economy; in Polish], Wyd. Akademickie Dialog, Warszawa

English translation: Matgorzata Mikulska 